\title{
BACTERIOLOGICAL AND PARASITOLOGICAL ASSESSMENT OF VAGINITIS IN PREGNANT WOMEN IN ISEYIN, OYO STATE, NIGERIA.
}

\author{
Adeyeba, O. A., Adeoye, M.O., Adesiji, Y. O. \\ Department of Medical Microbiology and Parasitology, \\ College of Health Sciences, Ladoke Akintola University of Technology. P .M. B. 4400, \\ Osogbo, Nigeria. \\ Correspondence to: Dr. O. A. Adeyeba
}

Specimens of High Vaginal Swabs (HVS) of 135 pregnant women were examined to determine the cause of vaginitis in pregnant women in Iseyin, Oyo State, Nigeria between August and October 1999. Study subjects were selected from patient attending selected antenatal clinics in public, private and mitsion hospitals/clinics in Iseyin. Samples were collected from subject in lithotomy position using sterile cuscos bivalve speculum. Sample were analysed by using standard technique as described. A structured questionnaire was also administered in order to obtain vital epidemiological information necessary for the study as described. The data analysis was done using chi square test. Results shows that $45(33.3 \%)$ were positive for Candida spp, $15(11.1 \%)$ for Gardnerella vaginalis and 5

$(3.7 \%)$ for Trichomonas vaginalis. Sexual activities of individual have no significant effect on prevalence of vaginitis while symptomatology was a major indicator of infection. The effect of educational attainment and religion on infection rate was discussed. Infection decreased with age of patients while infection distribution by age of pregnancy gave a confusing pattern and the factors responsible for this were discussed. Since vaginitis could be asymptomatic most time, the screening of all pregnant women with risk factors for preterm labour and premature rupture of membranes must be undertaken. Prompt treatment of cases is also recommended.

Key Words: Pregnant women, vaginitis, aetiologic agents, prevalence, Iseyin.

\section{INTRODUCTION}

Vaginitis is inflammation of the vaginal, a disease entity first described by Willinson (1). Abnormal vaginal discharge and related symptoms are frequent complaints in patients attending obsterics and gynaecology clinics and some form of vaginitis inducing organism, such as Candida albicans or Bacterial Vaginosis (BV) are commonly diagnosed. In acute vaginitis, the squamous epithelial lining of the vaginal wall is invaded and inflammed causing discomfort, pruritus, or pain in addition to discharge. There is no doubt that the microorganisms associated with cases of vaginitis frequently are isolated from asymptomatic women (2).

During pregnancy, the vaginal is more susceptible to infection, resulting in a higher incidence of colonization and sypmptomatic vaginitis. The clinical attack rate is increased maximally during the third trimester and symptomatic recurrence is also more common. Vaginitis has been observed in $61-90 \%$ of pregnant vaginal carriers as shown by Carrel et al (3).

Bacterial vaginosis (BV) is an entity receiving extensive attention 
in pregnancy and needs greater focus on the part of the clinicians. It is found in 15 to $23 \%$ of pregnant women with up to $50 \%$ of patients being asymptomatic $(4,5,6$.$) . The vulnerability of$ pregnant women to these infections is as a result of increased levels of oestrogen during pregnancy, which creates a climate for the growth of these agents (7).

Whereas so much work has been done on vaginitis and its aetiologic agents in other parts of the world, because of the importance of the subject, little or no work has been reported in Nigeria. Therefore this study is aimed at determining the prevalence of the aetiologic agents of vaginitis among pregnant women in Iseyin, Nigeria with a view to having a data base for planning effective case management and control of the problem.

\section{MATERIALS AND METHODS Study area}

The study was conducted in Iseyin in Iseyin Local Government Area of Oyo State between August and October 1999. Iseyin, with a population of about 79,838 (national census predominantly Yoruba, is located on the longitude 40.15E and latitude $8^{\circ} \mathrm{N}$, about 98 kilometers North of Ibadan, the Oyo State capital. Their main stay of economy is farming and trading with a reputation for the production of native fabrics called 'Aso Oke'. The town is endowed with many educational and health institutions both at primary and secondary levels. It is a community of mixed religions.

\section{Study subjects}

For the purpose of the study and sample collection, the hospitals and health institutions in the study area were grouped into 3-viz mission, public and private. The hospitals from each group were then randomly selected by balloting using lottery method. One hospital from each category was thus selected. The chosen hospitals for the study were: Our lady catholic hospital (mission), central maternity centre (public) and faith foundation hospital (private) respectively. The target population was pregnant women in Iseyin and those included in the study were those with symptom of vaginitis as recommended by Thomason et al (8). Most of the women who presented themselves in the hospital were in the third trimester.

\section{Sample collection}

One hundred and thirty five high vaginal swab samples were collected from pregnant women attending the antenatal clinic in the three hospitals enlisted in the study. Non- pregnant women on postnatal visit were included in the 
study as controls. Specimens were collec: d with the assistance of clinical staff, with patents in lithotomy posi,..n using sterile coscos bivalve speculum. A stretured questionnaire sheet was used to obtain information such as age, educational level, trimester, religion, occupation, marital status, number of sexual partners, symptoms and other important questions about their social life.

\section{Sample analysis}

Cultures were done on «odified Brain Heart Haeme agar, a multipurpose medium by using the conventional rolling method and incubated anaerobically at $37^{\circ} \mathrm{C}$ for 48 hours. All isolates were identified using the method described by Cruickshank et al (9) and characterized using the criteria of Cowan and Steel (10). Wet mount preparation for isolation of protozoa was done. The slide was prepared by suspending the discharge on the swab in a drop or two saline previously placed on the glass and examined microscopically using $\mathrm{x} 10$ and $\mathrm{x} 40$ objectives to scan at least ten fields for protozoa, Trichomonas vaginalis and yeast cells.

\section{Data analysis}

Data were analysed statistically using the Chi-square test to determine the significance of some variable where applicable; a $p$ value of $<0.05$ was considered significant.

\section{RESULTS}

Table 1 shows the distribution of isolates from pregnant women in Iseyin. Of 135 subjects examined, $45(33.3 \%)$ were positive for Candida albicans, 15 (11.1\%) for Gardnerella vaginalis and $5(3.7 \%)$ for Trichomonas vaginalis. Data revealed that infection rate with these agents differ significantly with age of the patients $(p<0.05)$. Generally, there were mixed infections with some other bacterial agents. Table 2 shows the distribution of infective agents by number of pregnancies. Result reveals that infection decreases with number of pregnancies. There was a significant difference when rates were analysed using the chisquare test $(p<0.05)$. Fig 1 shows infection rate by sexual activities. There was no significant difference in infection rate between subjects with single and those with multiple sexual partners $(p>0.05)$. Also women who had intercourse during pregnancy were more infected than those who did not. However, the difference was not statistically significant $(p>0.05)$. Table 3 shows infection rate by trimester. Data revealed that the age of pregnancy did not affect infection rate distribution ( $p>0.05$ ). Table 4 shows distribution by symptomatology and actiological agents. There were higher infection rates among 
women with symptoms of discharge and itching than those without any symptoms. The chisquare test revealed significant difference in infection rate between patients that presented with symptoms and the control group without any symptom $(\mathrm{p}<0.05) . \quad$ Table 5 shows distribution by marital status. Infection rates were higher among the married and polygamous than all other groups. Statistically however, the difference was not significant $\quad(p>0.05) . \quad$ The distribution of agents of vaginitis by educational level is shown in Table 6. Marginally there is a decrease in infection rate with educational level, and there was a zero percent infectivity of all the agents of vaginitis among women with tertiary education. However, the difference was not statistically significant ( $p>0.05)$. The result of the distribution of infective agents by occupation is presented in Table 7. There is a variation in prevalence with no definite pattern. The statistical analysis revealed that there was no significant difference in the infection occurrence rate between the occupational groups ( $p>0.05$ ). Table 8 shows distribution of infection by religion. There was $48 \%$ infectivity among muslims and $34 \%$ infectivity among christians. The Chi-square test revealed no statistical significant. difference between the two ( $p>0.05)$.

Table 1: Distribution of agents of vaginitis and other bacterial isolates by age.

\begin{tabular}{|l|l|l|l|l|l|l|l|l|}
\hline & \multicolumn{7}{|c|}{ Isolate distribution } \\
\hline $\begin{array}{l}\text { Age } \\
\text { y:s })\end{array}$ & $\begin{array}{l}\text { Number } \\
\text { Examuned }\end{array}$ & Candida spp \% & G. vaginalis & T. vaginalis & Stropt. Spp. & Kleb șpp & E.coli & Staph spp \\
\hline$\leq 20$ & 30 & $11(36.7 \%)$ & $2(6.7 \%)$ & $0(0)$ & $0(0)$ & $9(30 \%)$ & $5(16.7 \%)$ & $25(83.3 \%)$ \\
\hline $21-25$ & 55 & $17(30.9 \%)$ & $8(14.6)$ & $2(3.63 \%)$ & $5(9.1 \%)$ & $13(23.6 \%)$ & $11(20 \%)$ & $43(78.2)$ \\
\hline $26-30$ & 38 & $13(34.2)$ & $13(10.5)$ & $3(7.89 \%)$ & $2(5.3 \%)$ & $7(18.4 \%)$ & $10(26.3 \%)$ & $30(78.9 \%)$ \\
\hline $31-35$ & 10 & $3(30 \%)$ & $1(10 \%)$ & $0(0)$ & $0(0)$ & $2(20 \%)$ & $3(30 \%)$ & $9(90 \%)$ \\
\hline $\begin{array}{l}36 \& \\
\text { above }\end{array}$ & 2 & $1(80 \%)$ & $0(0)$ & $0(0)$ & $0(0)$ & $2(100 \%)$ & $0(0 \%)$ & $2(100 \%)$ \\
\hline Total & 135 & $45(33.3 \%)$ & $15(11.1 \%)$ & $5(3.7 \%)$ & $7(5.2 \%)$ & $33(24.4 \%)$ & $29(21.5 \%)$ & $109(80.7 \%)$ \\
\hline
\end{tabular}

Table 2: Distribution of infection by number of pregnancy

\begin{tabular}{|l|l|l|l|l|l|}
\hline $\begin{array}{l}\text { No of } \\
\text { pregnancy }\end{array}$ & $\begin{array}{l}\text { Total No examined } \\
(\%)\end{array}$ & Candida spp & G.vaginalis & T. vaginalis & Total No infected \\
\hline 1 & $45(33.3 \%)$ & $15(33.3 \%)$ & $4(8.9 \%)$ & $1(2.2 \%)$ & $20(44.4 \%)$ \\
\hline 2. & $41(30.4 \%)$ & $16(39.9 \%)$ & $4(9.8 \%)$ & $1(2.4 \%)$ & $21(51.2 \%)$ \\
\hline 3. & $16(11.9 \%)$ & $5(31.3 \%)$ & $1(6.3 \%)$ & $0(0)$ & $6(37.5 \%)$ \\
\hline$\geq 4$ & $15(11.1 \%)$ & $3(20 \%)$ & $4(26.7 \%)$ & $0(0)$ & $7(46.7 \%)$ \\
\hline
\end{tabular}


Table : Distribution by Trimester

\begin{tabular}{r|l|l|l|l|l|l|}
\hline & Trimester & $\begin{array}{l}\text { Total No } \\
\text { samined (\%) }\end{array}$ & Candida spp & G.vaginalis & T. vaginalis & $\begin{array}{l}\text { Total No } \\
\text { infected }\end{array}$ \\
\cline { 2 - 7 } & First & $4(2.9 \%)$ & $3(75 \%)$ & $0(0)$ & $0(0)$ & $3(75 \%)$ \\
\cline { 2 - 7 } & Second & $29(21.5 \%)$ & $6(20.7 \%)$ & $3(10.3 \%)$ & $1(3.4 \%)$ & $10(34.5 \%)$ \\
\cline { 2 - 7 } & Third & $102(75.5 \%)$ & $36(35.3 \%)$ & $12(11.8 \%)$ & $4(3.9 \%)$ & $52(50.9 \%)$ \\
\hline
\end{tabular}

$P>0.05$

Table 4: Distribution by symptomatology and aetiologic agents

\begin{tabular}{|l|l|l|l|l|l|}
\hline Symptoms & $\begin{array}{l}\text { Total No } \\
\text { examined } \\
135(\%)\end{array}$ & Candida (\%) & G.vaginalis (\%) & T. vaginalis (\%) & $\begin{array}{l}\text { Total No } \\
\text { infected (\%) }\end{array}$ \\
\hline Discharge & $127(94.1 \%)$ & $44(34.6 \%)$ & $12(9.4 \%)$ & $5(3.9 \%)$ & $61(48.0 \%)$ \\
\hline $\begin{array}{l}\text { No } \\
\text { discharge }\end{array}$ & $8(5.9 \%)$ & $1(12.5 \%)$ & $3(32.5 \%)$ & $0(0)$ & $4(50 \%)$ \\
\hline Itching & $57(42.2 \%)$ & $25(43.9)$ & $3(5.3 \%)$ & $5(8.8 \%)$ & $33(57.9 \%)$ \\
\hline No itching & $78(57.8)$ & $20(25.6 \%)$ & $12(15.4 \%)$ & $0(0)$ & $32(41.1 \%)$ \\
\hline $\begin{array}{l}\text { Itching+ } \\
\text { discharge }\end{array}$ & $57(42.2 \%)$ & $27(47.4 \%)$ & $3(5.3 \%)$ & $5(88 \%)$ & $35(61.4 \%)$ \\
\hline $\begin{array}{l}\text { Discharge } \\
+ \text { no } \\
\text { itching }\end{array}$ & $70(51.9)$ & $18(25.7 \%)$ & $10(14.3 \%)$ & $0(0)$ & $28(40 \%)$ \\
\hline $\begin{array}{l}\text { Control } \\
\text { (Neg) }\end{array}$ & $8(5.9)$ & $1(12.5 \%)$ & $3(37.5 \%)$ & $0(0)$ & $4(50 \%)$ \\
\hline
\end{tabular}

$P>0.05$

Table 5: Distribution of agents of vaginitis by marital stafus

\begin{tabular}{|c|c|c|c|c|c|}
\hline Marital Status & $\begin{array}{l}\text { Total No } \\
\text { examtned } \\
(\%)\end{array}$ & $\begin{array}{l}\text { Candida spp } \\
(\%)\end{array}$ & $\begin{array}{l}\text { G.vaginalis } \\
(\%)\end{array}$ & $\begin{array}{l}\text { T. vaginalis } \\
(\%)\end{array}$ & $\begin{array}{l}\text { Total No } \\
\text { infected }\end{array}$ \\
\hline $\begin{array}{l}\text { Married \& } \\
\text { polygamous }\end{array}$ & $49(36.3 \%)$ & $20(40.8 \%)$ & $7(14.3 \%)$ & $O(0)$ & $27(55 \%)$ \\
\hline $\begin{array}{l}\text { Married \& } \\
\text { monogamous }\end{array}$ & $58(42.9 \%)$ & $17(29.3 \%)$ & $4(6.9 \%)$ & $1(3.4 \%)$ & $22(37.9 \%)$ \\
\hline Single & $28(20.7 .5 \%)$ & $8(28.6 \%)$ & $4(14.3 \%)$ & $O(0)$ & $12(42.9 \%)$ \\
\hline
\end{tabular}

$P>0.05$ 
Table 6: Distribution of agents of vaginitis by educational level

\begin{tabular}{|l|l|l|l|l|l|}
\hline $\begin{array}{l}\text { Educational } \\
\text { level }\end{array}$ & $\begin{array}{l}\text { Total No } \\
\text { examined } \\
(\%)\end{array}$ & $\begin{array}{l}\text { Candida } \\
(\%)\end{array}$ & $\begin{array}{l}\text { G.vaginalis } \\
(\%)\end{array}$ & $\begin{array}{l}\text { T. vaginalis } \\
(\%)\end{array}$ & $\begin{array}{l}\text { Total No infected } \\
(\%)\end{array}$ \\
\hline Non-formal & $37(27.4 \%)$ & $12(32.4 \%)$ & $6(16.2 \%)$ & $2(5.4 \%)$ & $20(54.1 \%)$ \\
\hline Primary & $54(40 \%)$ & $12(38.9 \%)$ & $2(3.7 \%)$ & $2(3.7 \%)$ & $25(46.3 \%)$ \\
\hline Secondary & $41(30.4 \%)$ & $12(29.3 \%)$ & $7(17.1 \%)$ & $1(2.4 \%)$ & $20(48.8 \%)$ \\
\hline Tertiary & $3(2.2 \%)$ & $0(0)$ & $0(0)$ & $0(0)$ & $0(0)$ \\
\hline
\end{tabular}

$$
P>0.05
$$

Table 7: Distribution of agents of vaginitis by occupation

\begin{tabular}{|l|l|l|l|l|l|}
\hline Occupation & $\begin{array}{l}\text { Totai No } \\
\text { examined } \\
(\%)\end{array}$ & $\begin{array}{l}\text { Candida } \\
(\%)\end{array}$ & $\begin{array}{l}\text { G.vaginali } \\
\text { s(\%) }\end{array}$ & $\begin{array}{l}\text { T. } \\
\text { vaginalis } \\
(\%)\end{array}$ & $\begin{array}{l}\text { Total No } \\
\text { infected (\%) }\end{array}$ \\
\hline Trader & $97(71.9 \%)$ & $35(36.1 \%)$ & $12(12.4 \%)$ & $5(5.15 \%)$ & $52(53.6 \%)$ \\
\hline Civil servant & $5(3.7 \%)$ & $1(20 \%)$ & $1(20 \%)$ & $0(0)$ & $2(40 \%)$ \\
\hline Farmer & $5(3.7 \%)$ & $1(20 \%)$ & $0(0)$ & $0(0)$ & $1(20 \%)$ \\
\hline Artisan & $24(17.8 \%)$ & $7(29.2 \%)$ & $1(4.2 \%)$ & $0(0)$ & $8(33.3 \%)$ \\
\hline Housewife & $4(2.9 \%)$ & $1(25 \%)$ & $2(25 \%)$ & $0(0)$ & $2(50 \%)$ \\
\hline
\end{tabular}

$$
P>0.05
$$

Table 8: Distribution of agents of vaginitis by Religion

\begin{tabular}{|l|l|l|l|l|l|}
\hline Religion & $\begin{array}{l}\text { Total No } \\
\text { examined }\end{array}$ & $\begin{array}{l}\text { Candida } \\
\text { spp }\end{array}$ & G.vaginalis & T. vaginalis & $\begin{array}{l}\text { Total No } \\
\text { infected }\end{array}$ \\
\hline Christian & $23(17.0 \%)$ & $6(26.1 \%)$ & $2(8.7 \%$ & $0(0)$ & $8(34.8 \%)$ \\
\hline Muslim & $112(82.9 \%)$ & $39(11.6 \%)$ & $13(11.6 \%)$ & $5(4.5 \%)$ & $57(48.2 \%)$ \\
\hline
\end{tabular}

$P>0.05$ 


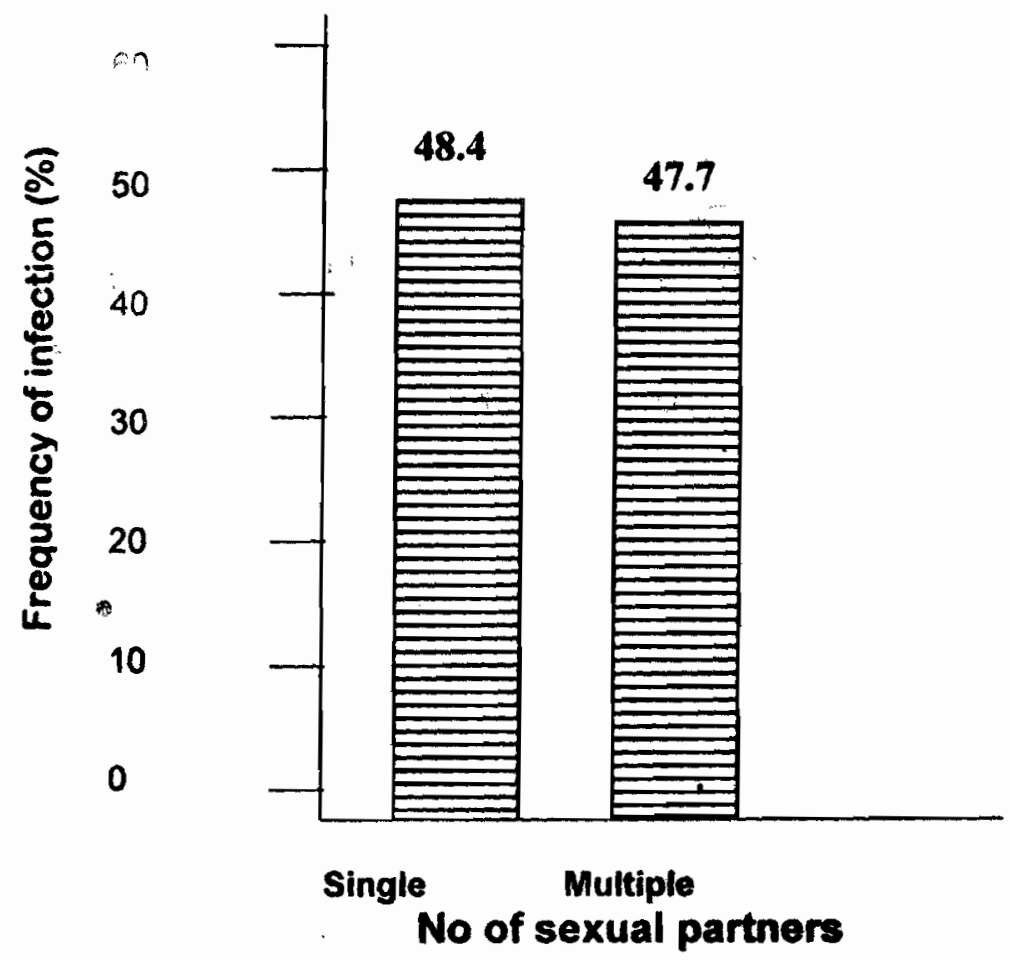

Figure 2a: Infection rate by sexual activities (Number of sexual partners)

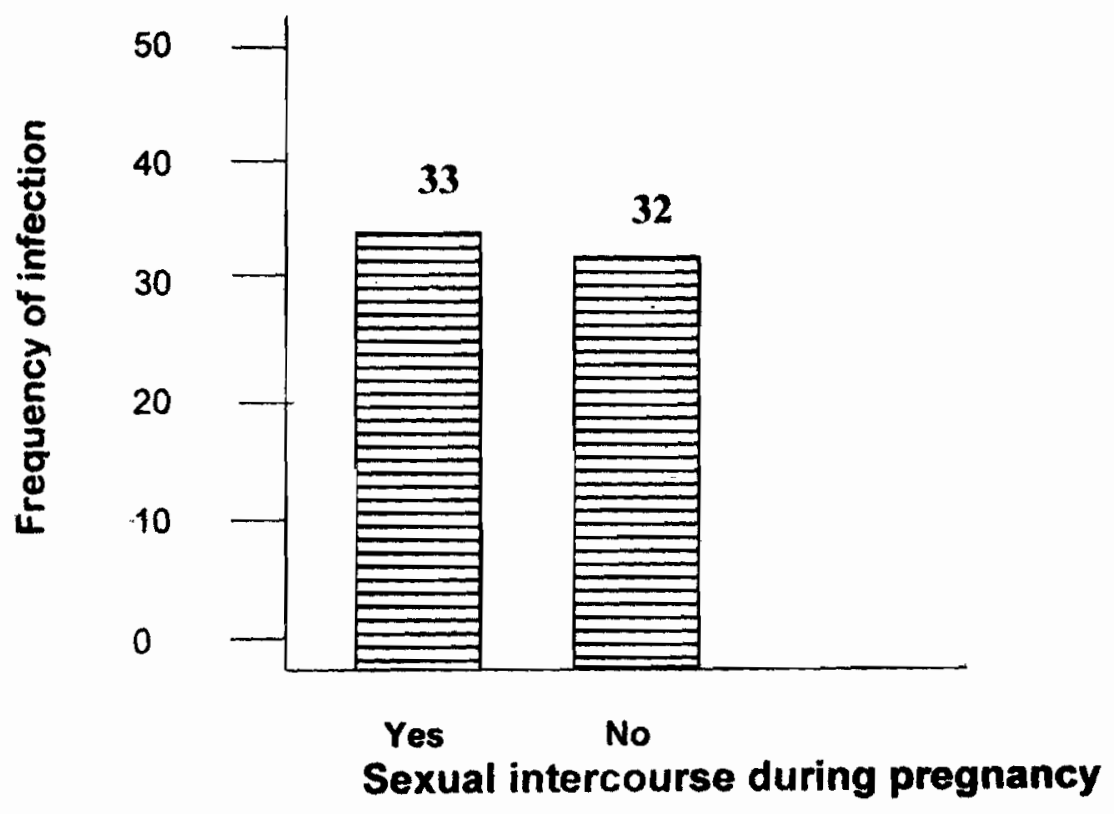

Figure 2b: Infection rate by sexual activities (intercourse during pregnancy) 


\section{DISCUSSION}

The study of microorganism incriminated as aetiologic agents of vaginitis serves to emphasis this complicated interaction that may exist between these microorganisms and the host. Studies have shown that organisms associated with vaginitis are part of the host's own microflora or exogenous microorganisms that must interact with species present as part of the host's indigenous flora (2). It has been shown in this study that the main organisms incriminated with vaginitis in pregnancy are Trichomonas vaginalis, Candida albicans and Gardnerella vaginalis. This confirms the observation of some authors (10). Candida albicans with the occurrence rate of $33.3 \%$ in Iseyin has been shown to be the commonest cause of vaginitis among the pregnant women in the area, a report, which is in consonance with the $30-40 \%$ prevalence reported by Hurley (12). This study has shown that $G$. vaginalis with $11.1 \%$ is second to Candida albicans in prevalence. Although this figure does not fall into the range (15.2\%) reported by Amsel et al (4), there is agreement in the position the parasitic infection occupies as the second most prevalent cause of vaginitis in pregnant women. Our report that Trichomonas vaginalis occurs less frequently is not controverted by other workers $(13,14)$. Mixed infections have remained a common occurrence in the study area. This is in conformity with the report of Lossick (14) who also agree that infection with these agents differ significantly with age of the patients $(p<0.05)$. Garber et al (15) also agree that there is an increased incidence of Trichomenas vaginalis in pregnancy. This study has shown that the occurrence rate of infective agents shows no definite pattern with the number of pregnancy $(p>0.05)$. This may not be unconnected with the level of health education among the populace. The subjects may have learnt from experience the need for prompt treatment as symptoms of infection manifest.

Result in this study has shown that age of pregnancy has no significant relevance in the distribution of infection $(p>0.05)$. This is at variance with the reports of Monton et al (16) and Hopsu-Havu (7), who showed that symptomatic disease is developed in about $10 \%$ of women during the first trimester and 36$55 \%$ during the third trimester. This disagreement in the report may be as a result of the attitude of the patients in our study area. Most of them ușually attend clinic only during the third trimester. This has brought about the imbalance in the numbers in the respective stages of 
pregna $\downarrow$, which may have accounted for the inference.

It has been shown in this study that sexual activities of the subjcets have no significant impact on the level of infection. There was no significant difference in the level of infection between women who had single sexual partner and those with multiple partners. This is an aberration from the belief that promiscuity and / or unfaithfulness premised on infidelity are a major sidemiological fartor of disease diffusion. The fact of the case may be due in part to regular case treatment, or those partners do not operate outside the regulars who may be bacteriologically clean. It was also observed in this study that sexual intercourse during pregnancy does not necessarily promote infection, as there is no statistical difference in the infection rate between those pregnant women who claimed to engage in sexual intercourse during gestation, and those who denied. Therefore, it could be safe to assume that when sexual activity is restricted faithfully to one partner (that is zero grazing) the health of the individual is not thrown into jeopardy. However, the incidence of infection was significantly higher in women married into polygamous setting than those in monogamous homes. On the contrary the data in Table 5 revealed that there is no significant difference between married women and the single pregnant women. This revelation presents a paradoxical picture-as opposed to the general belief that sexual promiscuity among partners do expose them more to risk of infection (14). Besides, these patients are at greater risk of contacting HIV. This is a subject of future investigation.

This study has shown that symptomatology and infection rates are linearly related. There were higher infection rates among subjects with vaginal itching and discharge than those without these symptoms. The factors responsible had been enunciated by many workers $(15,17)$ who incriminated surface protease action on mucous membrane of the vaginal in cases of Trichonomoniasis. It has been shown that the level of education of women has effect on the incidence of vaginitis in the study area. The uneducated and illiterate were mostly infected. Although the infection rate decreases with the level of education, the difference was not statistically significant $(p>0.05)$. This study also showed that religious belief and occupation had no effect on the distribution of infection among the study population ( $p>0.05$ ).

Whereas the infection could be either symptomatic or asymptomatic, many workers 
$(11,12,18,19)$ had documented the pathogenesis and sequelae of the infection. The disease could lead to premature rupture of membranes in pregnancy, preterm labour and procure abortion. The infection may predispose the patients to HIV infection and other opportunistic infections with grave consequences. Therefore, it is recommended that pregnant women must register in the antenatal clinic within the first trimester for adequate and timely management. It is of paramount importance for the pregnant women to undergo periodic screening in order to forestall preterm labour and premature rupture of membranes.

\section{ACKNOWLEDGEMENT}

We are greatly indebted to Dr. Ojo of Faith Foundation Hospital, Iseyin for being our linkman to other hospitals in Iseyin. We also appreciate the hospital workers for their support during the study.

\section{REFERENCES}

1. Olner-Hanssen O. Clinical manifestation of vaginal Ttrichomoniasis. JAMA. 1989 ; 264 : 471-576.

2. Krieger JN, Tam MR, Steven CE. Diagnosis of Trichomoniasis. Comparision of conventional wet mount examination with cytologic studies, cultures and monoclonal antibody staining of direct specimens. JAMA. $1988^{\circ} ; 259$ : 1223-1227.

3. Carrel CJ. Criteria for diagnosis of vulvovaginitis in pregnant women. J.Obstet. Gynaecol. Br. Com. 1973 ; 80 : 258.

4. Amsel R, Totten PA, Spiegel $C A$. Non-specific vaginitis: diagnostic criteria and microbial and epidemiologic associations. Am. J. Med. 1983. 74 : 14-22.

5. Gravelt M C, Nelson HP, DeRoven $T$. Independent association of $\mathrm{BV}$ and Chlamydia trachomatis infection with adverse pregnancy outcome. JAMA. 1986 ; 226 : 1899-1903.

6. Hill LV, Luther ER, Yung JD. Prevalence of lower genital tract infections in pregnancy. Sex. Transm. Dis. 1988 ; 15 : 5-10.

7. Hopsu-Havu KK. Vaginal in parturition and infestation of newborns. Acta. Obstet. Gynaecol. Scand. 1980 ; 59 : 73.

8. Thomason JL, Gelbart SM, Anderson RJ. Statistical evaluation of diagnostic criteria for BV. Am. J. Obstet. Gynaecol. 1990 ; 162 : 155160. 
9. Cruickshank R, Duguid JP, Narmion BP, Swain RHA. In: Medical Microbiology. The Practice of Medical Microbiolog $12^{\text {th }}$ edition. Churchill Li hostone. 1975.

10. Cowan ST, Steel J. Manual for the identification of the medical bacteria $2^{\text {nd }}$ edition Cambridge University Press. 1975:45-114

11. Spiegel CA, Amsel RKK. Diagnosis of BV by direct Gram stain of vaginal fluid. J. Clin Gynecol. $1981 ; 8$ : 209.

12. Hurley R. Recurrent candida infection. Clin. Obstet. Gynecol. $1981 ; 8$ : 209.

13. Rein MF, Muller M. Trichomonas vaginalis and Trichomoniasis. In: Holmes KK, Mardt PA, Sparling AF et al (eds). Sexually Transmitted Diseases. McGraw Hill, New York. 1989 : 481-492.

14. Lossick JG. Epidermiology of urogenital Trichomonias. In: Honinbery BM (ed). Trichomonads parasitic in humans. Springen Verlag, New York. 1989 : 311-323.

15. Garber G E, Lemchuk-Fawer LT, Bowie WR. Isolation of a cell-detaching factor of Trichomonas vaginalis $J$. Clin. Microbiol. $1989 ; 27$ : 1548.
16. Morton RS, Rashid M. Candidal vaginitis; natural history, predisposing factors and prevention. Proceeding of Royal Society of Medicine 1977 : 70-73.

17. Arroyo R, Alderete JF. Trichonmonas vaginalis surface protein activity is necessary for parasitic adherence to epithelial cells. Infect. Immum. 1:989; 57 : 2991- 2997.

18. Rain MF. Clinical manifestations of urogenital Trichomoniasis in women. In: Honinbery BM (ed). Trichomonads parasitic in humans. Spring Hill, New York. $1990 ; 225-234$.

19. Douglas IJ. Mannoprotein adhesive of Candida albicans. In: Bennet JE, Hsy RJ, Retuson PK (eds). New Strategies in fungal diseases: Churchill Livingstone. Edinburgh. 